\title{
Comparison of follicular heterogeneity and ovarian characteristics in Meishan and Large-White hybrid pigs
}

\author{
C. Biggs ${ }^{1}$, J. E. Tilton ${ }^{2}$, J. Craigon ${ }^{1}$, G. R. Foxcroft ${ }^{3}$, C. J. Ashworth ${ }^{4}$ \\ and M. G. Hunter ${ }^{1}$
}

${ }^{1}$ AFRC Research Group on Hormones and Farm Animal Reproduction, Faculty of Agricultural and Food Sciences, University of Nottingham, Sutton Bonington, Leics, LE12 5RD, UK; ${ }^{2}$ Department of Animal and Range Sciences, North Dakota State University, Fargo, ND 58105, USA; ${ }^{3}$ Department of Animal Science, University of Alberta, Edmonton, Canada, T6G 2P5; and ${ }^{4}$ Rowett Research

Institute, Aberdeen, AB2 9SB, UK

\begin{abstract}
Comparisons were made between characteristics of pre-ovulatory follicles recovered from prolific Chinese Meishan gilts $(n=12)$ and from European Large-White hybrid gilts $(n=13)$ in the late follicular phase preceding their fifth oestrous cycle, to determine whether there is an ovarian basis for the enhanced prolificacy in the Meishan. A total of 177 follicles per breed was classified as pre-ovulatory, based on follicular fluid oestradiol concentrations. Results obtained demonstrated high variability in all follicular characteristics in both breeds and no decrease in heterogeneity was evident in the Meishan. The Meishan follicles tended to be smaller $(P<0.06)$ and had less follicular fluid $(P<0.005)$, but total oestradiol content per follicle was similar $(P>0.1)$ with the result that the concentration of oestradiol in follicular fluid tended to be higher $(P<0.06)$ in Meishan than Large-White hybrid pigs. There were no differences between breeds in terms of testosterone concentration in follicular fluid, hCG binding to granulosa cells or total DNA content of granulosa cells. Concentrations of inhibin in follicular fluid were similar in both breeds $(P>0.1)$ which resulted in a trend towards less total inhibin content in Meishan than Large-White hybrid follicles $(P=0.065)$. Corpora lutea were recovered from both breeds $(n=12$ per breed) on days 27-31 of pregnancy after mating at first, second and third oestrus:corpora lutea were smaller $(P<0.001)$ and contained less progesterone per corpus luteum in the Meishan $(P<0.05)$ than in Large White hybrid pigs. However, since ovulation rate was higher in these particular Meishan pigs $(P<0.005)$, total ovarian progesterone content per animal was similar in both breeds. These results demonstrate that there was no decrease in the variability in follicular characteristics from Meishan pigs. However, both follicles and corpora lutea were smaller in Meishan than in Large-White hybrid pigs, and progesterone per corpora lutea was also lower in the Meishan. In spite of their smaller size, Meishan follicular oestradiol content was similar to that of Large-White hybrid pigs, such that the oestradiol concentration in follicular fluid tended to be higher in Meishan follicles.
\end{abstract}

\section{Introduction}

The Chinese Meishan breed of pig is extremely prolific compared with European breeds, and can produce up to $30-40 \%$ more live piglets per litter (Bolet et al., 1986; Bazer et al., 1988a, b; Haley and Lee, 1990). The precise physiological basis for this enhanced prolificacy is unknown as yet, but cross-breeding studies have indicated that it is a result of genes acting in the mother (Haley and Lee, 1990), which could be effective either through the oocyte or uterus. The greater number of piglets produced by the Meishans appears to be due mainly to increased prenatal survival (Bidanel and Legault, 1986; Bazer et al., 1988a; Haley et al., 1990). Conflicting reports have been presented about

Received 13 March 1992 whether the Meishans experience a higher ovulation rate (Bolet et al., 1986; Bazer et al., 1988a, b; Ashworth et al., 1990; Biggs et al, 1990) which could also contribute to increased litter size.

Several studies have suggested that variation in the rate of preimplantation embryo development within a litter is a likely cause of the high embryonic loss in European breeds of pig (Anderson, 1978; Pope et al., 1986; Pope et al., 1990), and indeed Bazer et al. (1988b) reported an increased uniformity of blastocyst development in the prolific Meishans. Furthermore, there is evidence that the variation in embryogenesis in European pigs is the result of heterogeneity in the pre-ovulatory follicle population (Foxcroft and Hunter, 1985; Grant et al., 1989; Hunter et al., 1989; Hunter and Wiesak, 1990; Pope et al., 1990; Xie et al., 1990a, b, c). 
The aims of the present study, therefore, were to compare the characteristics of pre-ovulatory follicles and corpora lutea in Meishan and European Large-White hybrid pigs and to determine whether differences in heterogeneity in follicular development could provide a basis for differences in embryonic survival.

\section{Materials and Methods}

\section{Animals}

Twelve Meishan gilts and three Meishan boars were obtained from the Edinburgh Station of the Institute of Animal Physiology and Genetics Research at approximately 8 weeks of age. Thirteen prepubertal Landrace $\times$ (Landrace $\times$ Large White) gilts (Large-White hybrids) were obtained from the University of Nottingham herd. All gilts were group penned according to breed and checked daily for oestrous behaviour with mature vasectomized boars of the appropriate breed. Ovaries were recovered at slaughter or by ovariectomy on the day before the first day of their predicted fifth oestrus, based on the previous cycle lengths of each animal (equivalent to day 20 of the fourth oestrous cycle for an animal with a 21 day cycle).

\section{Collection and treatment of follicular tissue}

The handling and dissection of ovarian tissue, the collection of follicular fluid and the harvesting of granulosa cells were as described previously (Foxcroft et al., 1987; Grant et al., 1989; Hunter et al., 1989), and all follicles $\geq 4 \mathrm{~mm}$ diameter were recovered. Briefly, this involved measurement of follicular diameter after dissection and recovery of follicular fluid using a Hamilton syringe. The fluid was immediately diluted into $1 \mathrm{ml}$ Hanks Balanced Salt Solution containing Hepes buffer (Flow Laboratories, Irvine) followed by centrifugation at $160 \mathrm{~g}$ for $10 \mathrm{~min}$ to pellet any granulosa cells removed with the fluid. The supernatant was removed and stored at $-20^{\circ} \mathrm{C}$ for subsequent radioimmunoassay. The collapsed follicle was bisected and the granulosa cells removed by scraping into phosphate-buffered saline (PBS). These cells were added to the previous pellet and the total complement collected by centrifugation. This pellet was then resuspended in PBS-glycerol and frozen at $-196^{\circ} \mathrm{C}$ for subsequent analysis of human chorionic gonadotrophin (hCG) binding and deoxyribonucleic acid (DNA) content as described below.

\section{Collection and treatment of luteal tissue}

Ovaries were recovered from 12 pregnant Meishan gilts from the Edinburgh population which had been transferred to the Rowett Research Institute in Aberdeen, and from 12 contemporary pregnant Landrace $\times$ Large White (Large-White hybrid) gilts, on days 27-31 of pregnancy. Before pregnancy, Meishan gilts had experienced two or three oestrous cycles and the Large-White hybrid gilts had experienced one oestrous cycle. Six gilts of each breed were fed $20 \mathrm{mg}$ allyltrenbolone (Regumate: Hoechst, Hounslow, Middlesex) daily for 18 days before mating, since these animals were used as part of a larger study on embryo survival (not reported here). Dissected corpora lutea were frozen at $-20^{\circ} \mathrm{C}$ and transported to Nottingham where they were thawed and weighed. Progesterone was extracted from luteal tissue by homogenization in double distilled ethanol as described previously by Hunter $e$ t al. (1988).

\section{Hormone radioimmunoassays}

Oestradiol and testosterone concentrations in follicular fluid were determined directly without extraction as described and validated by Grant et al. (1989). Limits of sensitivity of the assays were 4.2 and $14.5 \mathrm{pg}$ per tube, respectively, and interand intra-assay coefficients of variation were 18.4 and $10.3 \%$ for oestradiol and 17.1 and $13.2 \%$ for testosterone, respectively.

Progesterone content of luteal tissue was determined from the ethanolic extract after evaporation to dryness and redissolving in buffer as described by Hunter $e t$ al. (1988). The limit of sensitivity of the assay was $10 \mathrm{pg}$ per tube and inter- and intra-assay coefficients of variation were 14.2 and $12.7 \%$, respectively.

Inhibin concentration in follicular fluid was determined as described by McNeilly et al. (1989). The sensitivity and interand intra-assay coefficients of variation were $2.5 \mathrm{pg}$ per tube, 11.4 and $7.6 \%$, respectively.

\section{${ }^{125}$ I-labelled hCG binding assay}

Determination of hCG binding capacity by granulosa cells was carried out as described previously by Foxcroft et al. (1987), with the modification that after removal of the cells from liquid nitrogen and washing, cells were resuspended in $0.5 \mathrm{ml}$ PBS with $0.1 \%$ bovine serum albumin (Sigma Chemical Company Ltd, Poole). Four aliquots of $50 \mu \mathrm{l}$ were used for the binding assay and the remainder used for DNA estimation. Specific activity of the iodinated hCG was 99 c.p.m. $\mathrm{pg}^{-1}\left(59.5 \mu \mathrm{Ci} \mu \mathrm{g}^{-1}\right)$, and the active fraction was $35 \%$. Inter- and intra-assay coefficients of variation were 2.9 and $5.5 \%$, respectively.

\section{DNA assay}

The DNA content of an aliquot of granulosa cells from each follicle was determined according to the method of Labarca and Paigen (1980), and the range of the standard curve was 1.25 to $20 \mu \mathrm{g}$ DNA. The inter- and intra-assay coefficients of variation were 8.3 and $10.5 \%$, respectively.

\section{Statistical analyses}

Pre-ovulatory follicles were classified as those with a follicular fluid oestradiol concentration that fell above one standard deviation of the individual animal's overall mean follicular fluid oestradiol concentration: follicles which fell below were rejected as not destined to ovulate. It was decided that this was more appropriate than an arbitrary cut-off point, since follicular fluid concentrations varied not only within, but also between, animals. Predicted ovulation rates were compared between breeds by Student's $t$ test.

The following analyses were performed using the GENSTAT statistical package (GENSTAT 5 Committee, 1989). An analysis of 

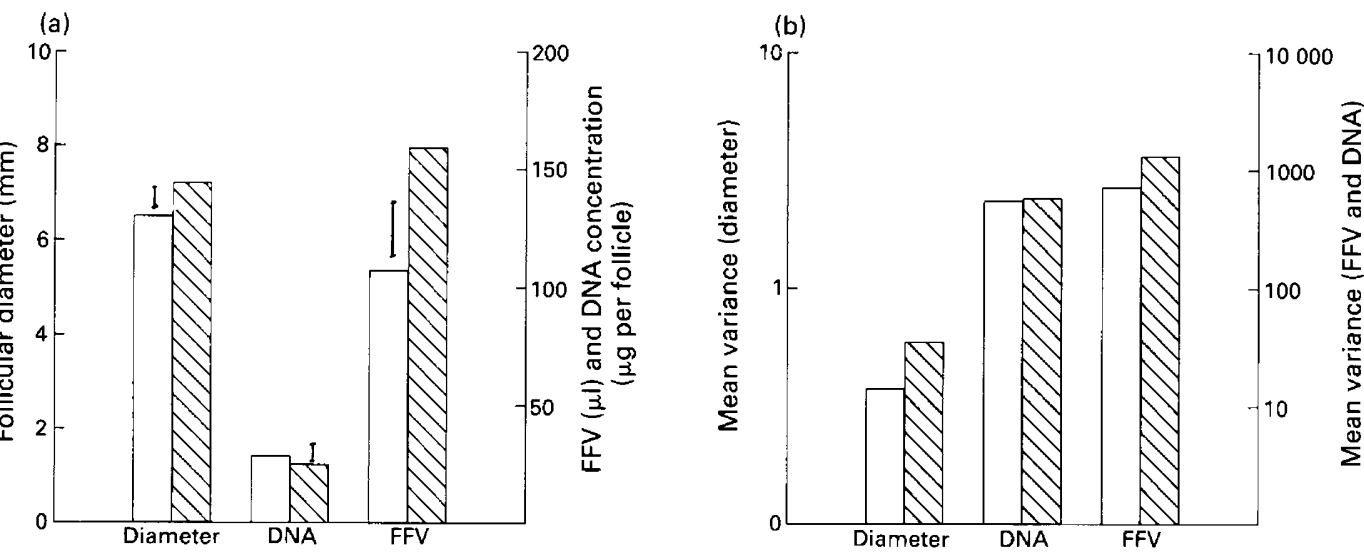

Fig. 1. (a) Means and SED of follicular diameter, follicular fluid volume (FFV) and DNA content ( $\mu$ g per follicle) of granulosa cells (DNA) of preovulatory follicles ( $n=177$ per breed) from Meishan $(\square ; n=12$ ) and Large White ( $\mathbb{\$} ; n=13$ ) gilts. (b) Mean variances of follicular diameter, follicular fluid volume (FFV) and DNA content of granulosa cells (DNA) of preovulatory follicles $(n=177$ per breed) from Meishan $(\square ; n=12)$ and Large White

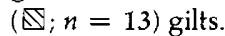

variance was used to assess differences between mean values of follicular characteristics between breeds and the pooled variance estimate used to calculate the standard error of the difference (SED). Since there was much variation within and between animals, significance levels of $P<0.07$ were considered to indicate a trend approaching significance, and thus have been included in the text. The heterogeneity of follicular characteristics was compared between breeds by analysis of deviance, and since independently estimated variances were being compared it was assumed that they followed a gamma distribution (McCullagh and Nelder, 1989). Linear correlation analysis was used to determine relationships between follicular characteristics in each of the breeds.

\section{Results}

\section{Morphological characteristics}

The total number of intact follicles $\geq 4 \mathrm{~mm}$ diameter recovered from Meishans ( $n=12$ ) was 223 and from Large-White hybrids $(n=13)$ was 256; a very small number (21) of follicles were burst during dissection, and rejected from any further analysis. A total of 177 follicles per breed was classified as pre-ovulatory, and thus the predicted mean ( \pm standard error of the mean (SEM)) ovulation rates per gilt were $14.8 \pm 1.66$ for Meishan and $13.6 \pm 2.14$ for Large-White hybrids $(P>0.1)$. These predicted ovulation rates are similar to those reported in both breeds during the fourth oestrous cycle (Biggs et al., 1990) and confirm that the classification of pre-ovulatory follicles based on oestradiol concentrations of follicular fluid is appropriate at this stage of the oestrous cycle. Mean diameter, volume of follicular fluid and DNA content of the granulosa cells of pre-ovulatory follicles of each breed are shown (Fig. 1a). Follicles from Meishan pigs tended to be smaller $(P<0.06)$ and contained less follicular fluid $(P<0.005)$ than Large-White hybrid follicles. Granulosa cell number per follicle as assessed by DNA measurement was not different between breeds $(P>0.1)$. There were no differences between breeds in variances in follicular diameter, follicular fluid volume or DNA content $(P>0.1)$ (Fig. 1b).

\section{Follicular fluid hormones}

The amount of hormone present in the follicular fluid was expressed as the concentration in $\mathrm{ng} \mathrm{ml}^{-1}$ of fluid and also as a total follicular content in $\mathrm{ng}$ per follicle. Follicular oestradiol content was similar in both breeds $(P>0.1)$ (Fig. $2 \mathrm{~b}$ ); however, follicles from Meishan pigs tended to have higher concentrations of oestradiol in follicular fluid than did follicles from Large-White hybrid pigs $(P<0.06)$ (Fig. 2a). The concentrations of the other hormones were not significantly different $(P>0.1)$, although follicular inhibin content showed a trend towards being higher in Large-White hybrid than in Meishan follicles $(P=0.065)$, and testosterone content was similar in both breeds $(P>0.1)$. Variances in follicular fluid hormone concentrations and total follicular hormone content were similar between breeds except for testosterone concentration which was more variable $(P<0.01)$ in Meishan than Large-White hybrid follicles (Fig. 2c, d).

\section{${ }^{125}$ I-labelled hCG binding to granulosa cells}

Mean binding to granulosa cells per follicle was not different between the breeds $(P>0.1)\left(323 \times 10^{3}\right.$ versus $378 \times$ $10^{3}$ c.p.m. bound per follicle for Meishan and Large-White hybrids, respectively, $\left.\operatorname{SED}=60.3 \times 10^{3}\right)$. Variances were also similar between breeds $(P>0.1)$.

\section{Characteristics of corpora lutea}

There were no differences in any of the characteristics measured in either breed between animals that had been treated with allyltrenbolone and those that had not, so data were combined within breeds. A total of 238 and 186 corpora lutea were recovered from Meishan and Large-White hybrid gilts, respectively, and mean ovulation rate was significantly greater 

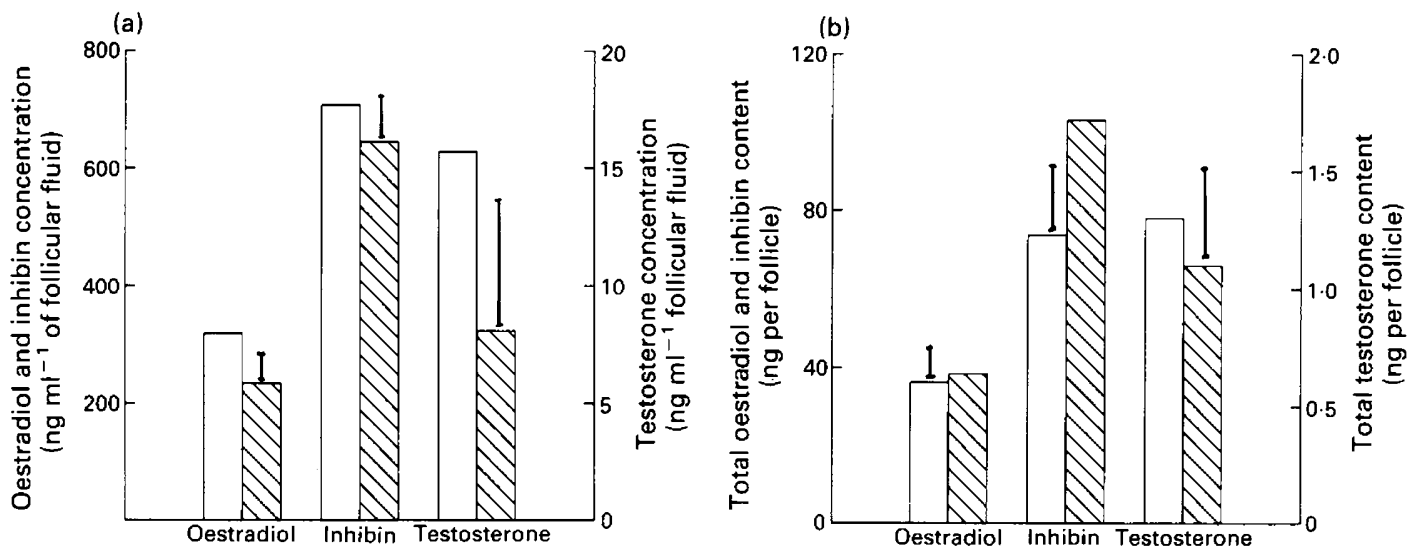

(c)
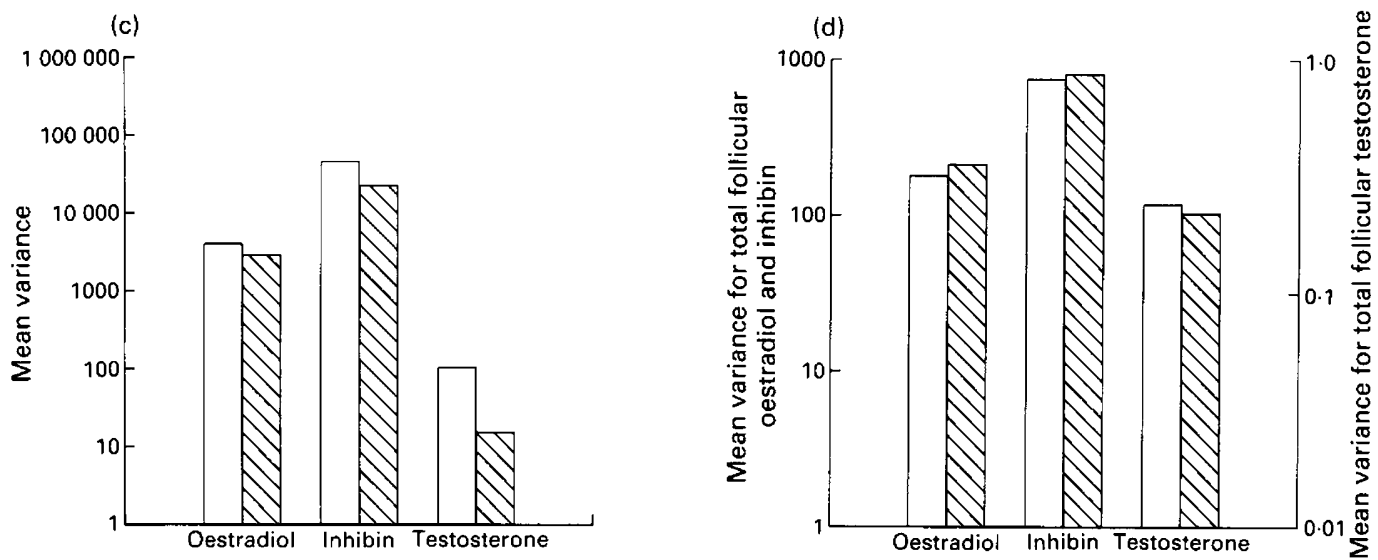

Fig. 2. (a) Means and SED of oestradiol, inhibin and testosterone concentration (ng $\mathrm{ml}^{-1}$ ) in the follicular fluid of preovulatory follicles. (b) Means and SED of total follicular oestradiol, inhibin and testosterone content (ng per follicle) in preovulatory follicles. (c) Mean variances of oestradiol, inhibin and testosterone concentration (ng $\mathrm{ml}^{-1}$ ) in the follicular fluid of preovulatory follicles. (d) Mean variances of total follicular oestradiol, inhibin and testosterone content (ng per follicle) of preovulatory follicles. For all graphs, follicle number $=177$ per breed from Meishan ( $\square$; $n=12)$ and Large White ( $\mathbb{Q} ; n=13)$ gilts.
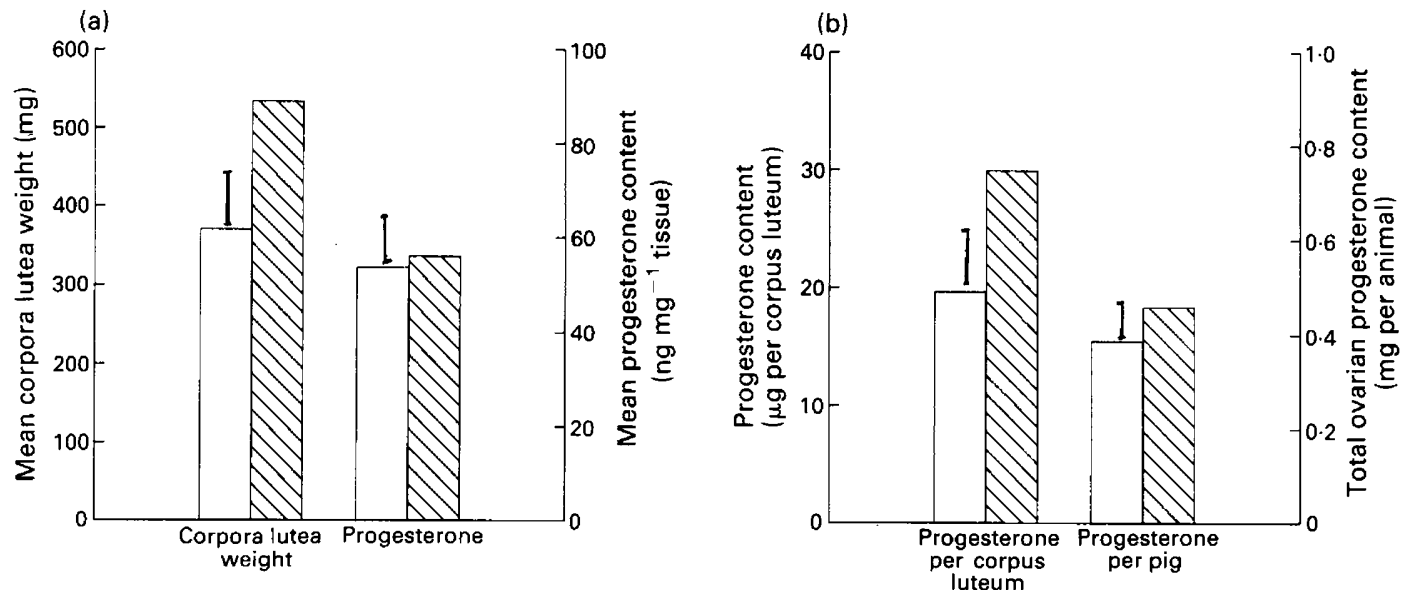

Fig. 3. (a) Mean and SED for weight of corpus luteum (mg) and progesterone content (ng $\mathrm{mg}^{-1}$ tissue) from Meishan $(\square)$ and Large White $(\mathbb{Q})$ gilts $(n=12$ per breed). (b) Mean and SED for progesterone content ( $\mu g$ per corpus luteum) and total ovarian progesterone content (mg per animal) from Meishan ( $\square$ ) and Large White (\$) pigs $(n=12$ per breed). 
in Meishan than in Large-White hybrids pigs at 19.8 versus 15.5 SED $=1.3 ; \quad P<0.005$. Corpora lutea recovered from Meishan pigs were significantly lighter than those from LargeWhite hybrids $(P<0.001)$, whereas progesterone content, per mg, was similar (Fig. 3a). As a consequence, progesterone content per corpora lutea was significantly greater in LargeWhite hybrid than in Meishan pigs $(P<0.05)$, but because of differences in ovulation rates, overall ovarian progesterone content per animal was not different between breeds $(P>0.1)$ (Fig. 3b).

\section{Relationships between follicular characteristics and between breeds}

Correlation analysis between follicular characteristics ( $n=177$ per breed) for each breed revealed highly significant positive correlations $(P<0.001)$ between follicular diameter and fluid volume $(r=0.82,0.90$ for Meishan and Large-White hybrids, respectively). These two characteristics also correlated with hCG binding to granulosa cells $(r=0.44,0.57$ and $0.44,0.58$ for Meishan and Large-White hybrids and follicular diameter and fluid volume, respectively, $P<0.001$ ), oestradiol concentration in follicular fluid $(r=0.44,0.36$ and $0.46,0.32$ for Meishan and Large-White hybrids, respectively, $P<0.001$ ), total follicular oestradiol $(r=0.69,0.68$ and $0.83,0.71$ for Meishan and Large-White hybrids, respectively, $P<0.001$ ) and total follicular inhibin $(r=0.48,0.64$ and $0.65,0.70$ for Meishan and LargeWhite hybrids, respectively, $P<0.001$ ). The testosterone concentration in the fluid was negatively correlated with follicular diameter and fluid volume, respectively $(r=-0.34,-0.21$ and $-0.43,-0.30$ for Meishan and Large-White hybrids, respectively, $P<0.01$ ). Oestradiol, inhibin and testosterone fluid concentrations were positively correlated with total follicular oestradiol, inhibin and testosterone, respectively $(r=0.84$, 0.82 and $0.81,0.93$ and $0.47,0.53$ for Meishan and Large-White hybrids, respectively, $P<0.001$ ).

\section{Discussion}

The number of pre-ovulatory follicles recovered in the present study from the Large-White hybrid females is consistent with those reported previously (Clark et al., 1975; Grant et al., 1989; Wiesak et al., 1990). In addition, the predicted ovulation rates of 13.6 and 14.8 for Large-White hybrids and Meishan, respectively, are similar to the actual ovulation rates that have been reported for both breeds after an equivalent number of oestrous cycles (Bolet et al., 1986; Bazer et al., 1988a; Hunter et al., 1991). In contrast, higher ovulation rates have been reported in other studies carried out on the same population of Meishans when compared with European breeds (Haley et al., 1990; Ashworth et al., 1990), which is consistent with the higher ovulation rate in the gilts from which luteal tissue was obtained in the present study (Ashworth et al., 1992). We suggest that some of these discrepancies may be due to the number of oestrous cycles experienced by the animals of each breed at the time that comparisons are made, coupled with environmental influences.

Heterogeneity in the follicular population in pigs has been well documented (Foxcroft and Hunter, 1985; Hunter and Wiesak, 1990; Wiesak et al., 1990; Xie et al., 1990a, b, c), including the implications this could have for oocyte maturation, luteal function and early embryonic development. Pope et al. (1990) have demonstrated a skewed distribution in both oocyte maturation and the pattern of ovulation. It has been reported that ovulation occurs over a shorter time span in Meishan than in Large-White hybrid pigs (Martinat-Botte et al., 1989), and this, coupled with the increased uniformity of blastocyst development in Meishan pigs (Bazer et al., 1988b) led to the hypothesis that increased embryo survival may be a direct consequence of a more synchronous follicular population. However, there was no evidence of decreased variability in the Meishan follicles at the time studied.

There is little information currently available on the process of folliculogenesis in Meishan pigs. Although ovulation rates were similar in the gilts used for the present follicular study, Meishan pre-ovulatory follicles were smaller than their LargeWhite hybrid counterparts and thus contained less follicular fluid. Follicles are smaller in prolific breeds of sheep (Driancourt et al., 1985; Webb and Gauld, 1985; McNatty et al., 1986) than in less prolific breeds. A reduced granulosa cell content was also noted in Booroola and Finn ewes, compared with Romanov and non-prolific ewes (Driancourt et al., 1991). Previous studies in pigs have already highlighted the variability in granulosa cell number both within and between pigs (Foxcroft and Hunter, 1985; Grant et al., 1989) and this was observed again in the present study. There was no difference overall in granulosa cell number as estimated by DNA content between breeds, in spite of the fact that the Meishan follicles were smaller, but this may be a reflection of the high variability within animals.

An important point is that, although they were smaller, Meishan follicles contained a similar amount of oestradiol as their Large-White hybrid counterparts, such that the higher concentration in the fluid in the Meishan approached significance. This suggests that the Meishan follicles may have been at a more advanced stage of development in terms of the intrafollicular steroid environment. The basis for this enhanced oestradiol concentration in Meishan follicles is not yet clear, particularly since granulosa DNA content and hCG binding were not different between breeds. Of several possibilities, the most likely are (i) earlier activation of aromatase activity in Meishan follicles, since it is known that aromatase activation is one of the earliest steps in follicular maturation in the pig (Foxcroft and Hunter, 1985), (ii) aromatase activity being higher on a per cell basis in Meishan than in Large-White hybrid follicles, (iii) a delay in the paracrine inhibitory effect of oestradiol on steroidogenesis (Hunter and Armstrong, 1987) or (iv) simply the same number of granulosa cells producing oestradiol into a smaller volume of follicular fluid in Meishan pigs. Such differences in aromatase activity have been reported in Booroola ewes (McNatty et al., 1985), in which peak aromatase activity is achieved by smaller follicles than with non-prolific breeds. Furthermore, observations (C. Biggs, L. S. Faillace and M. G. Hunter, unpublished) have demonstrated an increase in aromatase activity of both the granulosa and theca cells in the Meishan follicles at day 20 of the cycle.

Evidence suggests that granulosa cell aromatase activity, certainly in the initial stages, is controlled by folliclestimulating hormone (FSH) acting via the adenylate cyclase system (Erickson and Hsueh, 1978; Ainsworth et al., 1990), but currently there is no information available on FSH secretion 
during the early follicular phase in Meishan pigs. During the late follicular phase at about the time of the luteinizing hormone (LH) surge, FSH concentrations were not significantly different between Meishan and Large-White hybrid pigs (Hunter et al., 1991). It has previously been shown that androgen substrate availability is a major limiting factor for oestradiol production by pig and sheep follicles (McNatty et al., 1984; Foxcroft and Hunter, 1985; Grant et al., 1989), and the theca tissue in Meishan follicles may have increased capacity to produce androgen substrate. Although there was no significant difference in follicular fluid testosterone concentrations between the two breeds, this could have resulted from enhanced conversion to oestradiol in the Meishan follicles.

The trend towards a lower total inhibin content of the Meishan follicles is of interest particularly since follicle number was not significantly different between breeds. A similar reduction in inhibin secretion by individual pre-ovulatory follicles has been reported for prolific Booroola and Romanov ewes (Driancourt et al., 1991), but these animals also secreted less oestradiol and in the case of the Booroola there were fewer granulosa cells. McNatty et al. (1985) also reported fewer granulosa cells; however, in this case, the preovulatory follicles contained more oestradiol at a smaller diameter.

The significant positive correlations between follicular diameter and follicular fluid volume in both breeds are consistent with previous observations (Grant et al., 1989). Hormone concentrations of follicular fluid correlated with their respective total follicular hormone content, in both Meishan and Large-White hybrid pigs. The morphological characteristics correlated significantly with hormone content indicating that for both breeds the larger follicles exhibited a higher oestradiol concentration and total inhibin and oestradiol content. Testosterone concentration however was higher in smaller follicles in both breeds.

Although the present study found no evidence of decreased variability of follicular characteristics in Meishan pigs, the trend towards a higher oestradiol concentration in follicular fluid may indicate advanced maturity of these follicles.

Corpora lutea were smaller in Meishan than in Large-White hybrid pigs although there was no difference in follicular granulosa cell DNA content, but follicles were indeed smaller; however, the corpora lutea were recovered from pregnant Meishan pigs that had experienced more oestrous cycles before mating. Again, smaller corpora lutea have been reported in the prolific Booroola ewe, and this has been thought to be due to the lower granulosa cell numbers in these ewes (Scaramuzzi and Radford, 1983). The other point is that the corpora lutea recovered for this study were obtained from Meishan with a higher ovulation rate, the possible reasons for which are discussed above. Progesterone concentration per mg of tissue was similar between the breeds indicating comparable steroidogenic capacity on a cellular basis. Owing to their smaller size, Meishan corpora lutea contained less total progesterone than Large-White hybrid corpora lutea, but the overall ovarian progesterone content was the same for both breeds owing to the higher ovulation rate in Meishan pigs. These observations on luteal function need to be repeated in animals with similar ovulation rates, as well as an assessment of circulating progesterone concentrations.

In conclusion, although the present study found no differences in follicular heterogeneity between the breeds, it has demonstrated some differences between Meishan and Large-White hybrid pigs in both follicular and luteal characteristics. In particular, follicles from Meishan pigs, although smaller, had a similar follicular oestradiol content to their larger Large-White hybrid counterparts and tended to have higher oestradiol concentration in the follicular fluid. This suggests that these follicles may have been at a more advanced stage of maturation than their Large-White hybrid counterparts and whether this is subsequently reflected in oocyte maturation is currently under investigation.

We acknowledge the AFRC for financial support: C. Biggs was in receipt of a MAFF postgraduate scholarship. We thank the NIDDK for the purified hCG, A.S. McNeilly for performing the inhibin assays, S. S. Lynch for providing the oestradiol antiserum, S. Woodward for her excellent technical assistance and the members of the Joint Animal Breeding Unit for their help with the animal work.

\section{References}

Ainsworth L, Tsang BK, Downey BR and Marcus GJ (1990) The synthesis and actions of steroids and prostaglandins during follicular maturation in the pig Joumal of Reproduction and Fertility Supplement 40 137-150

Anderson LL (1978) Growth, protein content and distribution of early pig embryos Anatomical Record 190 143-155

Ashworth CJ, Haley CS, Aitken RP and Wilmut I (1990) Embryo survival and conceptus growth after reciprocal embryo transfer between Chinese Meishan and Landrace $\times$ Large White gilts Joumal of Reproduction and Fertility 90 595-603

Ashworth CJ, Haley CS and Wilmut I (1992) Effect of Regumate on ovulation rate, embryo survival and conceptus growth in Meishan and Landrace $\times$ Large White gilts Theriogenology 37 433-443

Bazer FW, Thatcher WW, Martinat-Botte F and Terqui M (1988a) Sexual maturation and morphological development of the reproductive tract in Large White and prolific Chinese Meishan pigs Journal of Reproduction and Fertility 83 723-728

Bazer FW, Thatcher WW, Martinat-Botte F and Terqui M (1988b) Conceptus development in Large White and prolific Chinese Meishan pigs Journal of Reproduction and Fertility 84 37-42

Bidanel JP and Legault C (1986) Experimental and prospective aspects of the utilisation of prolific Chinese pig breeds in Europe Proceedings of the 37th Annual Meeting of the European Association for Animal Production Budapest, Hungary 1 104-105, Abstract

Biggs C, Hunter MG, Craigon J, Wilmut I, Tilton JE and Foxcroft GR (1990) A comparison of preovulatory follicles in Meishan and Large White pigs. In Symposium Sur Le Porc Chinois pp 41-42 (Abstract) Eds N Molenat and C Legault. Toulouse, France

Bolet G, Martinat-Botte F, Locatelli A, Gruand J, Terqui M and Berthelot F (1986) Components of prolificacy in hyperprolific Large White sows compared with the Meishan and Large White breeds Genetics, Selection, Evolution $18333-342$

Clark JR, First NL, Chapman AB and Casida LE (1975) Ovarian follicular development during the oestrous cycle in gilts following electrocautery of follicles Journal of Animal Science 41 1105-1111

Driancourt MA, Cahill LP and Bindon BM (1985) Ovarian follicular populations and preovulatory enlargement in Booroola and control Merino ewes Journal of Reproduction and Fertility 73 93-107

Driancourt MA, Fry RC, Campbell BK and McNeilly AS (1991) Granulosa cell content and production of steroids, inhibin and follicular peptides by large follicles from a range of prolific and non-prolific sheep breeds Journal of Reproduction and Fertility Supplement $43230-231$

Erickson GF and Hsueh AJW (1978) Secretion of 'inhibin' by rat granulosa cells in vitro Endocrinology 103 1960-1963

Foxcroft GR and Hunter MG (1985) Basic physiology of follicular maturation in the pig Journal of Reproduction and Fertility Supplement 33 I-19

Foxcroft GR, Shaw HJ, Hunter MG, Booth PJ and Lancaster RT (1987) Relationships between LH, FSH and prolactin secretion and ovarian follicular development in the weaned sow Biology of Reproduction 36 175-191

Genstat 5 Committee (1989) Genstat 5 Reference Manual. Clarendon Press, Oxford 
Grant SA, Hunter MG and Foxcroft GR (1989) Morphological and biochemical characteristics during ovarian follicular development in the pig Joumal of Reproduction and Ferlility 86 171-183

Haley CS and Lee GS (1990) Genetic components of litter size in Meishan and Large White pigs and their crosses Proceedings of the 4th World Congress of Genetics Applied to Livestock Production Edinburgh XV 458-461

Haley CS, Ashworth CJ, Lee GJ, Wilmut I, Aitken RP and Ritchie W (1990) British studies on the genetics of prolificacy in the Meishan pig. In Symposium Sur Le Porc Chinois pp 83-97 (Abstract) Eds N Molenat and C Legault. Toulouse, France

Hunter MG and Armstrong DT (1987) Oestrogens inhibit steroid production by porcine thecal cells Molecular and Cellular Endocrinology 50 165-170

Hunter MG and Wiesak T (1990) Evidence for and implications of follicular heterogeneity in pigs Journal of Reproduction and Fertility Supplement 40 163-171

Hunter MG, Southee JA and Lamming GE (1988) Function of abnormal corpora lutea in vitro after $\mathrm{GnRH}$-induced ovulation in the anestrous ewe Journal of Reproduction and Fertility 84 139-148

Hunter MG, Grant SA and Foxcroft GR (1989) Histological evidence for heterogeneity in the development of preovulatory pig follicles Journal of Reproduction and Fertility 86 165-170

Hunter MG, Biggs C, Ashworth CJ and Haley CS (1991) Ovarian function in Chinese Meishan pigs Biology of Reproduction 44 Supplement 1145 (Abstract)

Labarca $C$ and Paigen K (1980) A simple, rapid and sensitive DNA assay procedure Analytical Biochemistry 102 344-352

McCullagh P and Nelder JA (1989) Generalized Linear Models Chapman \& Hall New York

McNatty KP, Hudson NL, Henderson KM, Lun S, Heath DA, Gibb M, Ball K, McDiarmid JM and Thurley DC (1984) Changes in gonadotrophin secretion and ovarian antral follicular activity in seasonally breeding sheep throughout the year Journal of Reproduction and Fertility 70 309-321

McNatty KP, Henderson KM, Lun S, Heath DA, Ball K, Hudson NL, Fennin J, Gibb M, Kieboon LE and Smith P (1985) Ovarian activity in Booroola $\times$
Romney ewes which have a major gene influencing their ovulation rate foumal of Reproduction and Fertility 73 109-120

McNatty KP, Lun S, Heath DA, Ball K, Smith P, Hudson NL, McDiarmid J, Gibb M and Henderson KM (1986) Differences in ovarian activity between Booroola $X$ Merino ewes which were homozygous, heterozygous and non-carriers of a gene influencing their ovulation rate Journal of Reproduction and Fertility 77 193-205

McNeilly AS, Swanston IA, Crow W, Tsonis CG and Baird DT (1989) Changes in plasma concentrations of inhibin throughout the normal sheep oestrous cycle and after the infusion of FSH Journal of Endocrinology 120 295-305

Martinat-Botte F, Bazer FW and Terqui M (1989) Embryonic survival mechanisms in Chinese Meishan (MS) and hyperprolific Large White (LWh) gilts. In Third International Conference on Pig Reproduction Loughborough (Abstract 45)

Pope WF, Lawyer MS, Nara BS and First NL (1986) Effect of asynchronous superinduction on embryo survival and range of blastocyst development in swine Biology of Reproduction 35 133-137

Pope WF, Xie S, Broermann DM and Nephew KP (1990) Causes and consequences of early embryonic diversity in pigs Journal of Reproduction and Fertility Supplemen $40251-260$

Scaramuzzi RJ and Radford HM (1983) Factors regulating ovulation rate in the ewe Journal of Reproduction and Fertility $69353-367$

Webb R and Gauld IK (1985) Folliculogenesis in the sheep: control of ovulation rate. In Genetics of Reproduction in Sheep pp 261-274 Eds RB Land and DW Robinson. Butterworths, London

Wiesak T, Hunter MG and Foxcroft GR (1990) Differences in follicular morphology, steroidogenesis and oocyte maturation in naturally cyclic and PMSG/hCG-treated prepubertal gilts Journal of Reproduction and Fertility $\mathbf{8 9}$ $633-641$

Xie S, Broermann DM, Nephew KP, Geisert RD and Pope WF (1990a) Ovulation and early embryogenesis in swine Biology of Reproduction 43 236-240

Xie S, Broermann DM, Nephew KP, Bishop MD and Pope WF (1990b) Relationship between oocyte maturation and fertilization on zygotic diversity in swine Joumal of Animal Science 68 2027-2033

Xie S, Broermann DM, Nephew KP, Ottobre JS, Day ML and Pope WF (1990c) Changes in follicular endocrinology during maturation of porcine oocytes Domestic Animal Endocrinology 7 75-82 